\title{
Using Digital Video Games in Service Learning Projects
}

\author{
Scott Mensch and Azad Ali \\ Indiana University of Pennsylvania, \\ Indiana, PA, USA
}

\section{s.mensch@iup.edu; azad.ali@iup.edu}

\section{ABSTRACT}

This paper details the experience of a particular department in integrating digital video games into a service learning project. The department of Technology Support and Training program (TST) within the Eberly College of Business and Information Technology (ECOBIT) at Indiana University of Pennsylvania (IUP) has taken the initiative to integrate service learning projects into the ir courses. Various initiating proposals have taken place in regards to ideas for the selection of the service learning projects and the methods of their implementation. Among these initiatives is a project taken by faculty members to donate a digital video game to a senior citizen center within the community. The paper first provides a theoretical feedback on service learning projects in general and the steps that led these faculty members to select this idea for a service project. More details is given regarding the planning and implementation for this project including the procedures followed to collect funds for the video game and the selection of the senior citizen center.

Keywords: Service learning, technology service projects, video game service projects

\section{Introduction}

Service learning projects have been used in academic courses for some time. Ideas for service learning projects often seem to be straight forward such as cleaning the streets, visiting the elderly, teaching children how to read or similar projects that deem to provide service to an individual or to a community. The ideas for service learning projects have been increasingly integrated into technology courses as well. Some of these ideas include teaching elderly about computer literacy, donating computers to non-profit organizations or creating web sites to community-based agencies.

The emphasis of "service learning projects" may vary from one project to another. However, the main purpose has most often been to provide learning opportunities for the students while at the same time offer services for organizations or individuals alike. Sheffield (2005) explained about the general purpose of service learning:

"Service-learning provides the opportunity to apply classroom-developed knowl-

Material published as part of this publication, either on-line or in print, is copyrighted by the Informing Science Institute. Permission to make digital or paper copy of part or all of these works for personal or classroom use is granted without fee provided that the copies are not made or distributed for profit or commercial advantage AND that copies 1) bear this notice in full and 2) give the full citation on the first page. It is permissible to abstract these works so long as cred it is given. To copy in all other cases or to republish or to post on a server or to redistribute to lists requires specific permission and payment of a fee. Contact Publisher@InformingScience.org to request redistribution permission. edge and skills to a community problem thereby increasing the depth and understanding of know ledge and skill while solving a community problem through interaction with diverse community stakeholders (p. 1)". 
Technology educators often may have difficulty when selecting a service learning project for their courses and may have to be creative when selecting a project scope. This paper identifies how a TST faculty member designed a creative idea when choosing a service learning project for his technology training class.

The remainder of the paper is divided into four sections: First, a theoretical background is given about service learning in general. The second section include explanations about videos game system than was chosen for this project. The third section discusses the benefits of using video games for senior citizens. The fourth section elaborates on the experience of TST faculty on planning, selecting and implementing the service learning project being discussed here.

\section{About Service Learning Projects}

The term "Service Learning" has been used in different academic programs for a number of years. It was first introduced in 1967 to describe the educational philosophy of integrating classroom concepts with a related community service experience (Sanderson, 2003). Traditional service learning projects were limited to certain programs like education, English, and social science. However, this expanded into other areas of academic education as different programs began to use this same learning tool. Furthermore, the context within which such projects are selected, managed and implemented has also widened. Thus discussing the definition and meaning of the term "service learning" may shed some light on the vast uses of "service learning projects" in academia.

\section{Service Learning - Definition}

In a simple terms, Sanderson and Vollmar (2000) defined service learning as "the integration of classroom concepts and related community service experience (p. 222)". Ferguson and Liu (2006) noted that in service learning projects, "students apply the knowledge and skills they have gained in the classroom to the real-world problems of community-based (p. 127)". Other definitions described service learning projects more elaborately and discussed the term from different perspectives. The Community Campus Partnership for Health (CCPH) for example connected service learning with preparation and reflection as illustrated in the ir definition listed be low:

Service-learning is a structured learning experience that combines community service with preparation and reflection. Students engaged in service-learning provide community service in response to community-identified concerns and learn about the context in which service is provided, the connection between their service and their academic coursework, and their roles as citizens. (p. 1)

Chaytor (2003) on the other hand defined service learning as "a form of experiential education in which students engage in activities that address human and community needs together with structured opportunities intentionally designed to promote students with learning and development. Reflection and reciprocity are key concepts to service learning" (p. 226).

\section{Service Learning Projects - Scope:}

Service learning, like any other project, has components that make it function properly. These components constitute the elements that make it able to proceed to completion. Although various projects have different scopes, many common elements can be found in service learning projects. Based on the definitions and descriptions listed above, the scope of service learning projects may include the following elements: 
1- A project that deems to provide service to a live being (an individual or so), to an organization or to a community of people.

2- Students to work on project.

3- An educational course or any similar setting, such as student organizations, that assigns the service project to the students.

4- The main goal of the service project is on student learning first followed by providing the actual service.

\section{Service Learning Projects in Technology Courses}

Despite the increasing use of service learning projects in different academic programs, the same increase is not witnessed in computer technology related programs. Different examples can be cited to indicate that computer technology programs lag behind other disciplines in introducing service projects within the ir courses. Sanderson (2003) for example noted about the lack of visibility for computer science courses in terms of service learning projects:

Service-learning is a form of experiential learning that integrates classroom concepts with related community services. Computer science faculty and students stand to reap great benefit from the integration of service-learning practice and philosophy into curricula. Many faculty are already doing so, yet computer science is not very visible in the service-learning community. Similarly, servicelearning is not very visible in the computer science education community. (p. 83)

The point that can be derived from the statement above is that computer technology related programs are slower than other programs in adopting service learning project into the ir courses. However this slow adoption may not be related entirely to the programs themselves. A number of factors may contribute to this slow acceptance. Some of these factors are related to the nature of computer related programs, while others are related to the general perception of what makes a service and the philosophies that underpin service projects and their practices (Ali et al, 2008).

Despite the difficulties noted above regarding the implementation of service learning projects, there are still many programs that are introducing these kinds of projects into their classes. As this learning tool expanded out of traditional areas, a wider range of opportunities opened to technology faculty regarding the ir selection of service learning projects. Sanderson (2005) suggested the following opportunities for service learning projects in technology courses:

- Develop an information system for an organization's administrator.

- Develop a web site for an organization or school.

- Develop classroom software for a school.

- Network an organization's computer resources.

- Tutoring and other instructional activities.

The opportunities listed above note traditional scope of a technology based service learning project. Different other projects can be introduced using computer or related technology; however this may require faculty to think outs ide of what is traditionally taught in a technology training course. The following section illustrates one example of such thinking.

\section{About Digital Video Games}

Gaming in general is not a new phenomenon. Gillespie (1997) noted about that in general

Games are universal and are as old as humankind. Gaming boards and dice have been found in Crete, in Mesopotamia, in Greece and throughout the old Roman 
Empire. While games are considered frivolous today, this has not always been so. (p. 148)

Playing interactive games is known to provide a number of advantages. Some of these advantages extend to the individuals playing the game while others extend to the surrounding family and community. According to Al Mahmud et al. (2008), the following advantages can be gained from playing games:

1. Leisure for the game players. Example, someone playing a domino,

2. Engaging the individuals playing the game.

3. A form of socialization.

4. Improving quality of life of individual playing the game.

Gajadhar, Kort ,and Jsselsteijn (2008) noted that the social setting has an influence on the experience of playing games and that playing games against others is more fun than playing alone. In reality, game playing is considered by many as a key to socialization and interacting with others. In regards to computer games, Bernhaupt et al. (2008) noted that "game players enjoy computer games for their leisure and enjoyment factor, social reasons, the challenge they provide, and to use them as a platform for performance and self expression" (p. 3905).

But video games require the availability of additional hardware and software. In particular, video games require the following additional components:

- A video device or game console.

- A game controller (such as a mouse pad or a joystick).

- The game itself.

The components listed above have become more advanced and interactive over the past several decades. Some games became so engaging that it captured the attention of player for hours. However, the engaging characteristics of video games became a social problem as some attributed this to the de-socialization of many teenagers. Additionally, video games still were difficult to use for senior citizens for different reasons:

- The game controller, which was typically small and contained small buttons, was difficult for senior citizens to handle.

- Some video games required following complex set of procedures which made it difficult set for senior citizens to learn.

Al Mahmud et al. (2008) explained about the difficulty that the elderly encountered when playing video games:

Elderly people today mostly play low-tech games such as card games. They seem to be less inclined towards computer games than younger people are. Some contributing factors to this difference are obviously that they are less familiar with the games being offered and more afraid of the complexity involved in installing and playing the games. Another factor may however be that existing computer games simply deviate too much from the games that are familiar to the elderly, and that current games insufficiently take into account their real needs (or wishes). (p. 403)

\section{Digital Video Games and Senior Citizens}

Subsequent development in the computer, video and virtual reality fields led to the development of digital video games which represented a leap from the older traditional gaming designers. New digital video games have the following advantages over traditional video games: 
- Better video displays.

- Game controllers are easier to use as compared to traditional joysticks.

- A wider range of games to choose.

Due to these technological innovations, video game manufacturers realized that there was a market for products that involved more physical interaction $w$ ith the game. While originally targeted for younger adults and children, these games became increasingly popular with older adults. Jsselsteijn et al. (2007) noted the following about digital video design and senior citizens:

There are compelling social and financial reasons why game developers should think seriously about making their games interesting and accessible to elderly users. Digital games hold a significant promise for enhancing the lives of seniors, potentially improving their mental and physical wellbe ing, enhancing the ir social connectedness, and generally offering an enjoyable way of spending time. (p. 17)

With the introduction of wireless systems into the gaming world, individuals can play games such as bowling or golf that require movements similar to real-life. Unlike traditional video games, energy is required as real-life movements make it more exciting to play.

Digital video games have increased among senior elderly users (Jsselsteijn et al., 2007). Their simplicity led to more playing these games and as a result led to increase socialization among seniors (Gajadhar et al., 2008). Accordingly, some senior citizen centers have acquired these gaming devices. Despite this increase of use of video games, some training may still be needed to set up and use the system. While large centers can offset these costs, smaller centers do have the same financial luxury. For this reason a faculty member initiated a project that aims at donating a Nintendo Wii to a senior citizen center.

\section{The TST Program at IUP}

The Technology Support and Training (TST) department in the Eberly College of Business adn Information Technology (ECOBIT) at Indiana University of Pennsylvania (IUP) offers two bachelor degrees and one associate degree. The first Bachelor degree is in Business Technology Support while the second is in Business Education. The Associate degree is in Computer and Information Technology.

Service projects have been implemented in the TST department for a number of years, but they have been limited mainly to student clubs. The department has a number of organizations for their students and each club is usually advised by a faculty. The faculty advisor often works with the students in the club to implement particular service projects. However this scenario has changed and faculty in this department began integrating service projects into the ir courses.

A new initiative began in the fall 2008 semester to start a service project to donate a Wii gaming center to a senior citizens center in the community. IUP is located in a rural area, thus most centers in the area are smaller and have a low operating budget. In order to donate such a game controller, the following steps need to be followed:

1- Fundraising event to collect money for to buy the game controller.

2- Finding a senior citizens center in the area that can accommodate the system.

3- Install the controller on the senior center.

4- Train senior citizens on the use of Wii system.

Description: The project started in September 2008 by conducting a fundraising project. In previous years, the club purchased a number of towels that hold the University name and logo. These towels were sold at sporting and other events held on campus. The fund gathered paid for student's registration into local conferences and job fairs. The remaining funds were used to buy the 
Nintendo Wii and additional controller that will be donated the senior citizens center. This service learning project is in the final stages as facilities are being reviewed to see where the device will be donated. Once donated, the center will take ownership of the Nintendo Wii gaming center.

\section{Summary and Future Research}

This paper explained about introducing the use of video games in service learning projects. It focused the coverage on the experience of faculty teaching in the TST department at IUP. The paper started by outlining the history of service learning projects in general, and similar projects in computer technology programs. It illustrated the use of digital video games on senior citizens. The paper then focused the on the TST faculty members effort to incorporate the project into a technical training class.

Service learning projects have been at the forefront of the TST department technical courses. Two faculty members of this department have been pioneering the use of service projects in the ir technology courses. The two faculty members wrote about the use of such projects in the past. The same faculty members feel that is time to take a pause on writing on these projects and assess their work. Thus, it is the intention of the same faculty to survey their work and have ideas from the students as well as the service agencies on the feasibility of their past projects and suggestions for how to conduct future service projects. This survey will be analyzed and the results will be the subject of a future study by the same authors.

\section{References}

Al Mahmud, A., Mubin, O., Shahid, S., \& Martens, J. (2008) Designing and evaluating the tabletop game experience for senior citizens. Proceedings of the 5 th Nordic conference on Human-computer interaction: building bridges, 403-406. Retrieved Dece mber 11, 2008 from ACM Digital Library http://www.acm.org/dl

Ali, A., DeLorenzo, G., Mensch, S., \& Kohun, F. (2008). Integrating service learning projects into technology courses: The experience of two programs. Is sues in Information Systems, IX(1),121-128.

Bernhaupt, R., Jsselsteijn, W. I, Floyd, F., Tscheligi, M., \& W ixon, D. (2008). Evaluating user experiences in games. Proceeding of the conference on Human Factors in Computing Systems, 3905-3908. Retrieved December 10, 2008, from ACM Dig ital Library http://www.acm.org/dl

Chaytor, L. (2003). Urban empowerment: A successful example of service learning. CITC4, 03, October 16-18. Retrieved December 20, 2007, from ACM Digital Library http://www.acm.org/dl

Community Campus Partnership for Health. (2008). Service-learning. Retrieved March 15, 2008 from http://depts.washington.edu/ccph/servicelearningres.html

Ferguson, R., \& Liu, C. (2006). Service-learning projects: Opportunities and challenges. SIGSCE, March 1 5, 2006. Retrieved December 20, 2007, from ACM Digital Library http://www.acm.org/dl

Gajadhar, B., Kort, Y., \& Js selsteijn, W. I. (2008). Influence of social setting on player experience of digital games. CHI'08 extended abstracts on Human factors in computing systems, 3099-3104. Retrieved Dece mber 10, 2008 from A CM Dig ital Library http://www.acm.org/dl

Gillespie, T. (1997). Dig ital storytelling and computer game design. Proceeding of the Conference on Human Factors in Computing Systems, 148-149. Retrieved December 11, 2008, from A CM Digital Library http://www.acm.org/dl

Jsselsteijn, W. I., Nap, H., de Kort, Y., \& Poels, K. (2007) Digital game design for elderly users. Proceedings of the 2007 conference on Future Play, 17-22. Retrieved Dece mber 10, 2008 from ACM Digital Library http://www.acm.org/dl

Sanderson, P. (2003). Where's (the) computer science in service learning? Consortium for Computing Sciences in Colleges. Retrieved February 10, 2008 from ACM digital Library http://www.acm.org/dl 
Sanderson, P., \& Vollmar, K. (2000). A primer for applying service learning to computer science. Retrieved February 11, 2008, fro m ACM Digital Library http://www.acm.org/dl

Sheffield, E. (2005). Service in service-learning education: The need for philosophical understanding. High School Journal, 89(1), 46-53.

\section{Biographies}

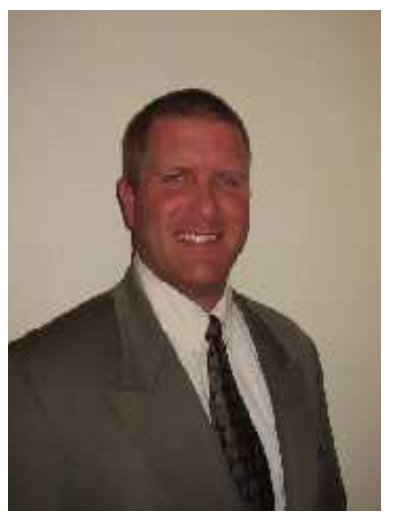

Scott Mensch, Ph.D., Assistant Professor of Technology Support and Training at Eberly College of Business Indiana University of Pennsylvania. Over the past 12 years he has held several positions in both IT and education and currently instructs and designs courses in both business and information technology in a traditional setting and online. Dr. Mensch completed his M.B.A. in 1998, and obtained two additional Associate Degrees in Computer Applications and Networking. In addition between 1999 and 2003 he also obtained his (CCNA) Cisco Certified Network Associate, (MCSA) Microsoft Certified 2000 Systems Administrator, (MCSE+I) Microsoft Certified Systems Engineer + Internet NT 4.0, A+ Computer Technic ian, and Server + Certifications. Dr. Mensch obtained his $\mathrm{PhD}$ in

Organizational Management with a Specialization in IT Management, and is currently completing post doctoral studies in telecommunications and IT security.

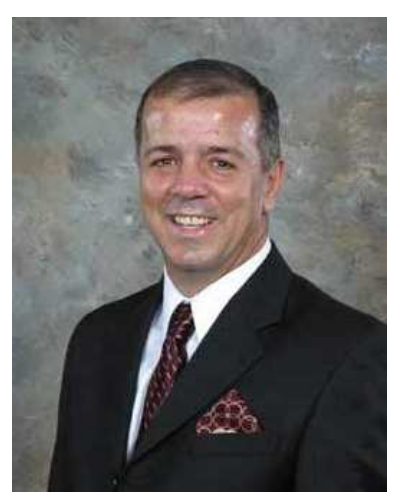

Azad Ali, D.Sc., Associate Professor of Technology Support and Training at Eberly College of Business - Indiana University of Pennsylvania has 23 years of combined experience in areas of financial and information systems. He holds a bachelor degree in Business Administration form the University of Baghdad, an M.B. A. from Indiana University of Pennsylvania, an M.P.A. from the University of Pittsburgh, and a Doctorate of Science in Communications and Information Systems form Robert Morris University. Dr. Ali's research interests include object oriented languages, web design tools, and curriculum design. His community service and academic expertise gets him in the news on Pittsburgh television and in the newspapers. 